\title{
Understanding India's Services Revolution
}

James Gordon and Poonam Gupta 


\title{
IMF Working Paper
}

Asia and Pacific Department

\section{Understanding India's Services Revolution}

Prepared by James Gordon and Poonam Gupta ${ }^{1}$

September 2004

\begin{abstract}
This Working Paper should not be reported as representing the views of the IMF. The views expressed in this Working Paper are those of the author(s) and do not necessarily represent those of the IMF or IMF policy. Working Papers describe research in progress by the author(s) and are published to elicit comments and to further debate.

This paper analyzes the factors behind the recent growth of India's services sector. The high growth of services output in the 1990s was mostly due to the rapid expansion of communication, banking, business services (including the IT sector) and community services. While factors such as a high income elasticity of demand for services, increasing input usage of services by other sectors, and rising exports, were important in boosting services growth in the 1990s, supply side factors including reforms and technological advances also played significant roles. Going forward, the growth potential of Indian services exports is well known, but the paper also finds considerable scope for growth in the Indian service economy provided that deregulation continues. In addition, the paper shows that employment growth in the Indian services sector has been quite modest, thus underscoring the need for industry and agriculture to also grow rapidly.

JEL Classification Numbers: E23, E24, L80, 011, 014, 040

Keywords: Services, sectoral shares, balanced growth, splintering, liberalization

Author(s) E-Mail Address: jgordon@imf.org, pgupta@imf.org

\footnotetext{
${ }^{1}$ This paper was written in the IMF New Delhi office and was presented at the IMF-NCAER India-China conference in November 2003. Papers presented at this conference are going to be published in a joint IMF-Palgrave volume, which is being edited by David Cowen and Wanda Tseng. We are grateful to Shankar Acharya, Martin Cerisola, Deepak Mishra, Ashoka Mody, Sudip Mohapatra, Uma Ramakrishnan, Michael Wattleworth, and Sanjay Hansda (Department of Economic Analysis, RBI) for helpful comments. We would also like to thank Mr. Kolli from CSO for assistance with the data. Errors remain our own.
} 


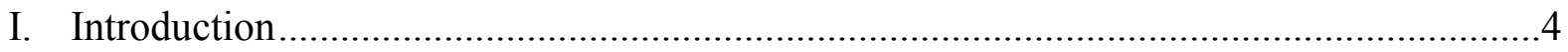

II. Growth and Sectoral Shares, Cross Country Evidence, and India's Experience................6

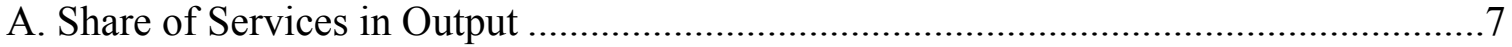

B. Share of Services in Employment .....................................................................

III. Which Services Have Grown Rapidly? .................................................................... 9

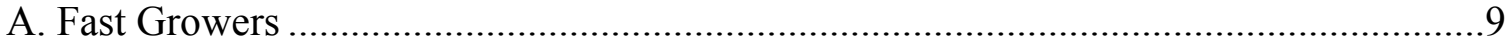

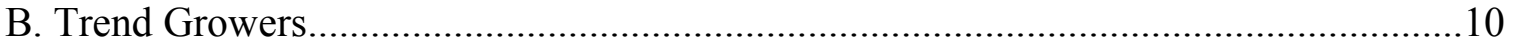

C. Contribution of Fast and Trend Growers in Services Growth ...................................10

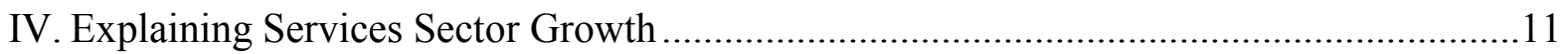

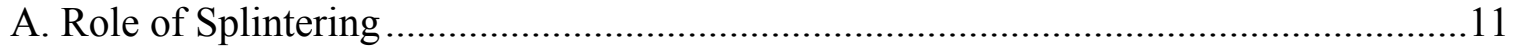

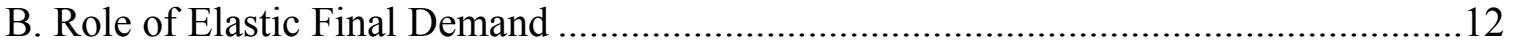

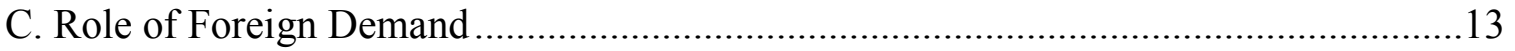

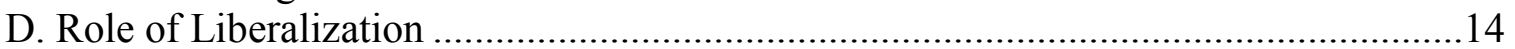

E. Quantifying the Contribution of Different Factors in Services Growth.......................15

V. Empirical Tests of Competing Hypotheses.................................................................... 15

A. Decade-Specific Dummies (Time Series Regressions) ...........................................16

B. Sector-Specific Liberalization Dummies (Panel Data Regressions) ............................17

VI. Summary and Conclusion .............................................................................. 18

Figures

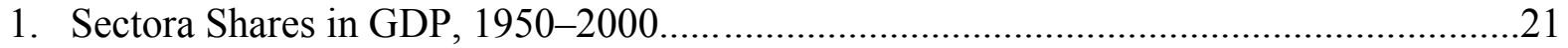

2. Cross Country Data on Per Capita Income and Share of Services in GDP ....................21

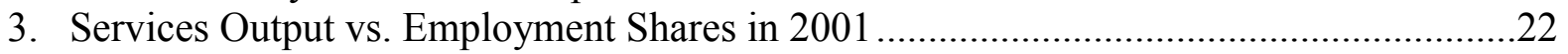

4. Growth Rate of Services Sector in India..................................................................22

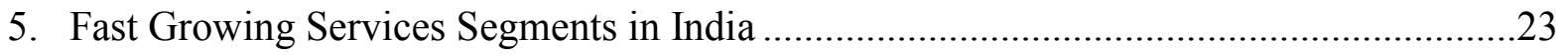

6. Contribution of Fast and Trend Growers to Growth in Services ...................................24

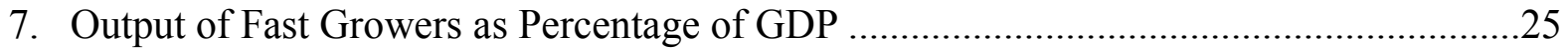

8. Price Deflator of Services Relative to the GDP Deflator .............................................26

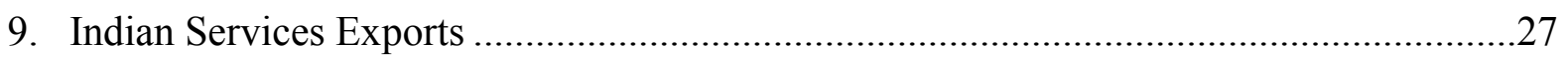

10. Composition of Services Exports from India.............................................................2 27

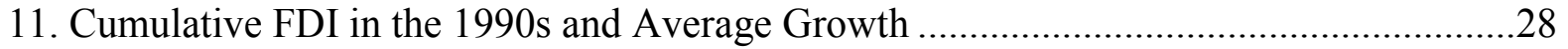

12. Increase in the Private Sector's Share and Average Growth .........................................28

13. Contribution of Different Factos in Explaining Growth in Services ..............................28 
Tables

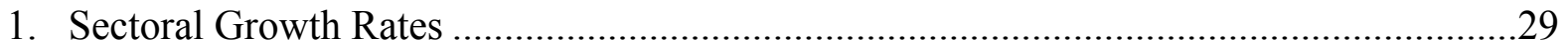

2. Sectoral Shares in GDP in 2001, Global Averages....................................................29

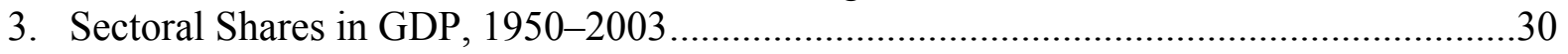

4. Share of Service Sector in Employment and Capital Formation .....................................30

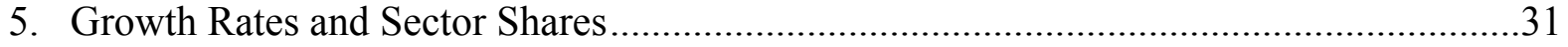

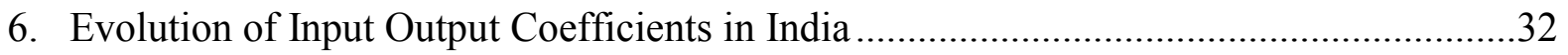

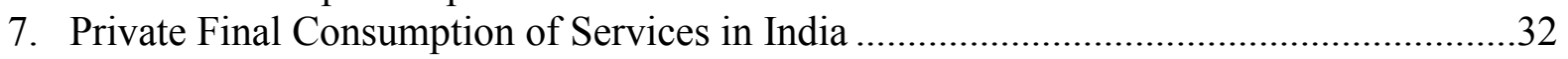

8. Growth Rates of Value Added and Final Consumption of Services and GDP..................32

9. Explaining Services Growth using Time Series Data, 1995-2000 ...............................33

10. Explaining Services Growth using Panel Data, 1970-2000 .........................................34

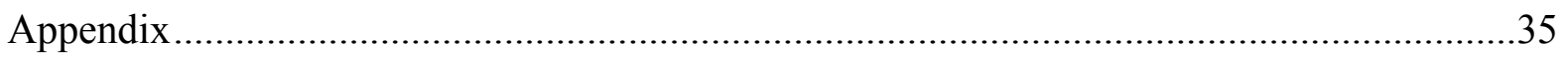

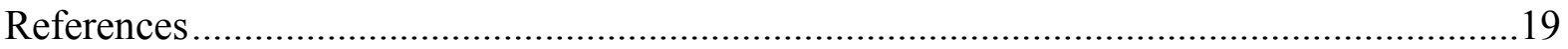




\section{INTRODUCTION}

A striking feature of India's growth performance over the past decade has been the strength of its services sector. Table 1 shows that on average services grew more slowly than industry between 1951 and 1990. Growth of services picked up in the 1980s, and further accelerated in the 1990s, when it averaged 7.5 percent a year, thus providing a valuable prop to industry and agriculture, which grew on average by 5.8 percent and 3.1 percent respectively. ${ }^{2}$ Most forecasters expect that services will grow at similar if not higher rates over the next few years. Growth in the services sector has also been less cyclical and more stable than growth in industry and agriculture (in the sense of having the smallest coefficient of variation).

The emergence of services as the most dynamic sector of the Indian economy has in many ways been a revolution. The most visible and well-known dimension of the take-off in services has been in software and information technology (IT)-enabled services (including call centers, software design, and business process outsourcing). However, growth in services in India has been much more broad-based than IT. In fact, although IT exports have had a profound impact on the balance of payments, the sector remains a small component of GDP. As of 2003, business services (which includes IT) were only about 13/4 percent of GDP, accounting for just 3 percent of total services output.

The paper shows that almost all service subsectors in India have grown faster than GDP over time, but the pick-up in growth in the 1990s was the strongest in business services, communication, and banking services, ${ }^{3}$ followed by hotels and restaurants and community services. These activities together account for the entire acceleration in services growth in the 1990s. The growth in public administration and defense, real estate, storage, transport, and personal services in the 1990s was broadly similar to that in the previous decades.

Rapid growth of the services sector is not unique to India. The existing literature shows that as an economy matures the share of services in output increases consistently. To begin with, the increase occurs along with an increase in the share of industry. Thereafter, the services share grows more rapidly, accompanied by a stagnant or declining share of the industrial sector. Consistent with this trend, India's growth experience has been characterized by a

\footnotetext{
${ }^{2}$ In the paper, we focus on decadal performance, although there are other ways of sub-dividing the data, such as plan periods. Indeed, Acharya (2003) observes that services growth in India was close to the trajectory of industrial growth from 1950 to 1996/7, but that a marked divergence emerged during the Ninth Plan period (1997-2002), when services grew at 8 percent and industry at only $4 \frac{1}{2}$ percent. In comparison to Table 1 , a focus on plan performance thus tends to make the services revolution look both more dramatic and more recent in origin.

${ }^{3}$ In this paper, banking services includes activities of commercial, post office, and savings banks, as well as nonbank financial institutions, cooperative credit societies, and employee provident funds. It excludes the insurance sector.
} 
decline in the share of agriculture in GDP and an increase in the shares of industry and services. Between 1951 and 2000, the share of agriculture in GDP fell from 58 to 25 percent, while the share of industry increased from 15 to 27 percent, and the share of services rose from 27 to 48 percent. Of particular note are the changes during the 1990s, when the share of services in India's GDP climbed by about 8 percentage points, as compared to a cumulative increase of 13 percentage points during 1951-90. The share of industry, by contrast, remained constant during the 1990s.

This paper explores the factors behind the dynamism of the services sector in India. One explanation suggested in the literature for fast growth in services is that the income elasticity of demand for services is greater than one. Hence, the final demand for services grows faster than the demand for goods and commodities as income rises. Another explanation is that technical and structural changes in an economy make it more efficient to contract out business operations that were done internally by individual firms. This type of outsourcing has been called the "splintering" of industrial activity. Splintering results in an increase in net input demand for services from the industrial sector, and the services sector growing proportionately faster than other sectors.

The empirical evidence presented in this paper shows that while splintering and high income elasticity of demand for services have served to stimulate services growth in India, it is necessary to look beyond these factors to fully explain the growth acceleration in the 1990s. In particular, important roles also seem to have been played by economic reforms, and growing demand for services exports. ${ }^{4}$

Looking forward, our analysis suggests that the Indian services sector may experience an extra impetus to growth in coming years from exports and from liberalization. New markets for Indian services exports are just beginning to be tapped and there is substantial scope for further high growth rates in tradable services. There is also scope for considerable growth from liberalization and the associated productivity gains in some of the services subsectors where growth has lagged behind in the 1990s. The distribution sector seems to be a prime candidate in this regard.

One caveat to our analysis is that the quality of the Indian national accounts data on services does not appear to be strong. Acharya (2003) shows that actual estimation of certain services

\footnotetext{
${ }^{4}$ There have also been industrial sector reforms in India, which begs the question why the industrial sector has not grown as fast as services. A number of explanations suggest themselves: (i) poor infrastructure has acted as a bottleneck to industrial growth (on the other hand, some service sectors such as transport, storage and communications would have been equally affected); (ii) labor restrictions and small-scale reservations have disadvantaged industry more than services; (iii) the service sector has received more generous tax incentives; and (iv) faster growing services activities seem to be more intensive in skilled labor, with which India is well endowed.
} 
is rather indirect and based on imprecise assumptions and lagged information. He also raises the issue that the change of base year to 1993-94 in the CSO data may have affected the continuity of data and inflated the output of services sector in the 1990s. While there is merit in these arguments, there is, unfortunately, no easy way to verify the data quality. However, the comparability of data can be assessed over time by looking for a distinct break in the time series. In this context, we could not find evidence of any significant breaks, including in 1993-94. On the contrary, what we see is the growth acceleration in different service activities starting in different years, and also to be spread over a number of years rather than being confined to just one year.

The rest of this paper is organized as follows. In Section II, we place India's growth experience in perspective by reviewing the existing literature and cross country evidence on sectoral transformation during growth. In Section III, we identify the services activities where growth was particularly high in the 1990s. In Section IV, we analyze the various possible factors behind the recent dynamism of the services sector. Section $\mathrm{V}$ provides econometric analysis of the importance of each competing hypothesis to explain growth, and Section VI concludes.

\section{Growth And Sectoral Shares, Cross Country Evidence ANd India's EXPERIENCE}

The evolution of the sectoral shares in output, consumption and employment as economies grow has been studied for well over fifty years. During the 1950s and 1960s, research by Kuznets and Chenery suggested that economic development would be associated with a sharp decline in the proportion of GDP generated by the primary sector, counterbalanced by a significant increase in industry and by a more modest increase in services. ${ }^{5}$ Sectoral shares in employment were predicted to follow a similar pattern.

With the benefit of more data than was available to Kuznets and Chenery, recent literature has tended to emphasize the growing importance of service sector activity, For example, Kongsamut, Rebelo and Xie (2001) analyze a sample of 123 countries for 1970-89 and show that rising per-capita GDP is associated with an increase in services and a decline in agriculture both in terms of share in GDP and employment. In other words, the sectoral share given up by agriculture as the economy matures goes more to the services sector and less to industry than the Kuznets-Chenery work had suggested. The modern view is that as an economy matures, the share of services (in output, consumption, and employment) grows

\footnotetext{
${ }^{5}$ Using pooled cross-section and time-series data, Chenery and Taylor (1968) found the industry share in GDP to be positively associated with income and population, and negatively associated with primary exports. This implied a tendency for industry to gain as income rose, but that the gain would be less pronounced in small countries with substantial natural resource endowments.
} 
along with a decline in agriculture. By contrast, the share of industry first increases modestly, and then stabilizes or declines.

\section{A. Share of Services in Output}

Such a pattern of growth is visible in the cross-country data on shares in GDP presented in Table 2. These data suggest two stages of development. In the first, both industry and services shares increase as countries move from low income to lower middle income status, while in the second, the share of industry declines and that of services increases as the economy moves to upper middle and higher income levels.

How does the Indian experience fit in with this pattern? Through the 1980s at least, the fit is quite close. Figure 1 shows that in the four decade period, 1950-90, agriculture's share in GDP declined by about 25 percentage points, while industry and services gained equally. The share of industry has stabilized since 1990, and the entire subsequent decline in the share of agriculture has been picked up by the services sector. Thus, while over the gain in the services sector share over the four decades, 1950s-1980s, was 13 percentage points, the gain in the 1990 s alone was 8 percentage points.

Consequently, at current levels, India's services share of GDP is higher than the average for other low income countries. A comparison of Tables 2 and 3 shows that the size of India's services sector, relative to GDP, is closer to the average of lower middle income countries.

Is India an outlier? The evidence suggests that though the Indian services sector is somewhat higher than the average, India is not that unusual. Figure 2 relates the share of services in GDP to the per capita income in 1990 and 2001 using data for various countries from the World Bank's World Development Indicators (WDI). ${ }^{6}$ As is shown by the fitted line, the share of services in GDP is associated positively with per capita income, i.e., the countries with higher per capita income also have a larger share of services in their GDP.

In 1990, the share of India's services sector in GDP was very close to the average share predicted by this linear relationship. As a result of rapid services growth in the 1990s, however, India's share in services had moved above the average share predicted by the cross country experience by as much as 5 percentage points of GDP by 2001 . Even so, in terms of having a large share of services in GDP, India is by no means an outlier. If different sectors in India grow at the average growth rates experienced in 1996-2000, then by 2010, the share of services would increase to 58 percent, which would bring the size of the India's services sector, relative to GDP, closer to that of an upper middle income country, even though India would still belong to the low income group.

\footnotetext{
${ }^{6}$ The sample includes countries with GDP more than US\$10 billion, for which the data are available in the World Bank's WDI (55 countries).
} 


\section{B. Share of Services in Employment}

Even though India has experienced profound changes in output shares, the same is not true for employment shares (Table 4). A striking feature of India's development is that in contrast to the substantial decline in the share of agriculture in GDP, there has been rather little change in the share of employment in agriculture (Bhattacharya and Mitra, 1990). Similarly, although services rose from 42 percent to 48 percent of GDP during the 1990s, the employment share of services actually declined by about one percentage point during the decade. Thus, while output generation has shifted to services, employment creation in services has lagged far behind. ${ }^{7}$ India's relatively jobless service sector growth is unlike the experience of other countries, where the service sector has also tended to gain a larger share of employment over time. India, in fact, has an exceptionally low share of services employment, when compared with other countries (Figure 3$).^{8}$

An interesting feature of Figure 3 is that the slope of the fitted line is greater than one. The normal pattern is thus for the share of services employment to rise faster than the share of output. This implies that labor productivity in services tends to fall as the service sector increases. ${ }^{9}$ In sharp contrast, since the labor share in services employment has been flat, labor productivity in Indian services has been increasing over time. In addition, the increase in labor productivity in Indian services has not been due to an increase in the relative capital intensity (Table 4). This suggests that other factors have been at work in raising labor productivity, which could include the growth of services being concentrated in subsectors that are more dependent on skilled labor than on unskilled labor or capital. This trend has no doubt been reinforced by technological improvements, as well as by efficiency gains resulting from liberalization (RBI, 2002). We return to these points in Section IV below.

\footnotetext{
${ }^{7}$ Some observers have stressed Indian employment data are not high quality. Even so, anecdotal evidence suggests that employment growth in some of the fast growing services subsectors has been quite modest. For example, the NASSCOM/McKinsey visions for the Indian IT sector predicts that exports will rise to US\$50-60 billion over the next few year, but that only a few million jobs will be created in the process.

${ }^{8}$ Employment data are available for fewer countries, thus the Figure includes only 32 of the 55 countries covered in Figure 2.

${ }^{9}$ Earlier evidence showed that the primary cause of the higher employment share of services in the United States was the slow growth of services productivity (Inman, 1985). However, subsequent work by Slifman and Corrado (1996) indicates that some of the apparent slow growth in labor productivity in services in the United States may be due to errors in measuring output and prices.
} 


\section{Which SERVICES HAVE GROWN RAPIDLY?}

In this section we identify the drivers of the acceleration of growth in the services. The data on annual growth rate over the past fifty years (Figure 4) suggest a structural break in growth in services starting in 1980. Through the 1970s, the growth path was more or less flat, but the trend shifted upwards in the 1980s and then perhaps again in the 1990s. By contrast, the growth path for industry, which exhibited a declining trend between 1954-80, has been flat over the past two decades.

The acceleration in services growth in the 1980s and 1990s was not uniform across different activities. Some sub-sectors grew at a much faster rate than in the past, while for other subsectors, growth rates were similar to the past trend (Table 5). To identify the growth-drivers within the services sector, we compare the growth rates of various activities in the 1990s with their previous trend growth rates (Figure 5). The trend growth rates are estimated using the three year moving average of the growth rate, with the period 1954-90 used in estimating the trend (except for banking for which the trend is estimated using the data to1980).

A comparison of the actual and the trend growth rates shows that growth in several service sub-sectors accelerated sharply in the 1990s (and for banking in the 1980s); indicating some sort of a structural break in their growth series. We call these activities fast growers. The remaining activities grew more or less at a trend rate; these we call trend growers.

\section{A. Fast Growers}

Based on the above criterion, fast growers were as follows:

- Business services (including IT) was the fastest growing sector in the 1990s, with growth averaging nearly 20 percent a year. Though disaggregated data for this category are not available, export and software industry data indicate that the growth was mainly on account of the IT sector. Despite being the fastest growing sector, business services, particularly IT activity, was growing off a low base and its contribution to the services sector and GDP growth was quite modest in the 1990s. As we discuss later, this segment is expected to continue growing at a very high rate and is likely to contribute more significantly to services growth in the future.

- Communication services, which registered growth of 14 percent a year during the 1990s, made a significant contribution to services growth. The growth in communication was mostly due to telecom, which accounts for 80 percent of output.

- In the banking sector, growth jumped from about 7 percent over the period 1950-80, to 12 percent in the $1980 \mathrm{~s}$, and 13 percent in the 1990s. Growth was most rapid in the NBFIs (which grew by 24 percent in the 1980s and 19 percent in the 1990s), followed by growth in the banks (by10 percent and 9 percent, respectively, in the 1980s 
and 1990s). Overall, the contribution of banking to services sector growth was larger than that of the communications sector.

- Community services and hotels and restaurants increased at the trend growth rate through the early 1990s, but experienced a pick up in growth in the latter part of the decade. In community services, this was due to both education and health services (70 percent and 23 percent of value added, respectively) growing at an average rate of 8 percent in 1990s.

\section{B. Trend Growers}

Among the trend growers, the growth rate of distribution services (the largest service subsector in India), averaged about 6 percent in the 1980s, higher than in previous decades, and accelerated further to about 7 percent in the 1990s-just below the threshold for fast growers.

The rate of growth of public administration and defense in the 1990s averaged 6 percent, which was similar to the growth experienced in previous decades. Growth spiked in response to the Fifth Pay Commission awards to government employees in the late 1990s, but this did not substantially increase average sector growth for the decade as a whole. ${ }^{10}$

The growth rate of personal services jumped to 5 percent in the $1990 \mathrm{~s}$, but remained below the growth in most other services activities. The other sub-sectors such as transport, dwellings, and storage grew more or less at the same rate in the 1980s and 1990s as in previous decades.

\section{Contribution of Fast and Trend Growers to Services Growth}

The fast growing activities accounted for about a quarter of services output in the $1980 \mathrm{~s}$, but because of their relatively fast growth, these activities represented one-third of services output by 2000 . We show the estimation of the average contribution of the fast growers and trend growers to services growth in the 1950s-1970s, the 1980s, and the 1990s in Figure 6. Based on our estimates, the high services growth in the 1980s was primarily due to the trend growing sub-sectors. These activities added about 1 percentage point of additional services growth in the 1980s, while fast growing activities made a contribution only about half as large. In the 1990s, by contrast, fast growing sectors made about the same contribution to

\footnotetext{
${ }^{10}$ Acharya (2002a) estimates that improper deflation of the effects of the Fifth Pay Commission in the National Accounts led to an overstatement of the growth of government services (that is public administration and defense) in the late 1990s. Hansda (2002) recognizes that there may have been some upward distortion in the estimates for a few years as a result of the Pay Commission, but note that this was not of sufficient magnitude to affect the trend in services growth, which increased in the 1990s, even if PAD is excluded altogether.
} 
services growth as the trend growing sectors. In fact, since the growth of trend growing sectors was about the same in both decades, the fast growers collectively accounted for almost all of the higher services growth in the 1990s. This is consistent with new activities and industries having sprung up in the fast growth sub-sectors, but not in the trend growth ones.

\section{EXPLAINING SERVICES SECTOR GROWTH}

A number of studies have attempted to explain the fast growth in the share of services activity observed in cross country data. The literature draws a distinction between demand and supply factors (Kravis, 1982, Francois and Reinhart, 1996). On the supply side, the output share of services can be boosted by a switch to a more services-input intensive method of organizing production. Such a change in production methods can arise as a result of increasing specialization as the economy matures. For example, over time, industrial firms may make greater use of specialist sub-contractors to provide services that were previously provided by the firms themselves. Legal, accounting, and security services are obvious candidates to be contracted out. Bhagwati (1994) calls this process of specialization splintering. Kravis (1982) points out that splintering can lead to growth in the share of services in GDP, even when GDP itself is not growing. On the demand side, an increase in the output share of services can arise from rapid growth in the final demand for services. This could be from domestic consumers with a high income elasticity of demand for services, or from foreign consumers with a growing demand for the country's service exports. Demandled growth of this type is likely to result, at least initially, in a rise in the prices of services, as well as a shift of resources into the production of services.

Services activity can also be stimulated by technological advances, whereby new activities or products emerge as a result of technological breakthrough - such advances are likely to be particularly relevant in the case of the IT and telecommunication sectors and to some extent in financial services (credit cards, ATMs etc.). Liberalization can also provide a boost to services. In India, important policy reforms were made in the $1990 \mathrm{~s}$ which were conducive to the growth of services sector, such as deregulation, privatization and opening up to foreign direct investment (FDI). If the growth of services was previously inhibited by government controls, then policy changes may provide a positive shock that unleashes new activity and growth.

\section{A. Role of Splintering}

As noted, changes in production technique can cause a firm to splinter, and, as a result, the proportion of output originating in the services sector to increase. Such splintering would be reflected in an increase in the use of services as intermediate inputs but not as final demand.

One way to estimate the importance of splintering to services growth in India is to measure the increase in input usage of services in other sectors through changes in the input-output coefficients. The matrices for different years show that the use of services sector inputs in 
industry increased by about 40 percent between 1979/80 and 1993/94; that is, the inputoutput coefficient increased from 0.15 to 0.21 (Table 6). In addition, the use of services inputs in agriculture almost doubled during this period, but still remained low (only 5 percent of the gross output).

Another way to show how important splintering has been in India is to look at the change in the input-output coefficients for services input in agriculture and industry, which increased by 0.03 and 0.04 , respectively, during the 1980s. These coefficient changes would have increased demand for services (as a first round effect) by:

$$
\Delta \mathrm{Y}_{\mathrm{S}}=0.03 \mathrm{Y}_{\mathrm{A}}+0.04 \mathrm{Y}_{\mathrm{I}}
$$

where $\mathrm{Y}_{\mathrm{i}}$ is the output in sector $\mathrm{i}$. Dividing through by total output $\mathrm{Y}$ and evaluating at the average sectoral shares during the $1980 \mathrm{~s}(0.35,0.25$ and 0.40 for agriculture, industry and services, respectively), yields:

$$
\Delta \mathrm{Y}_{\mathrm{S}} / \mathrm{Y}_{\mathrm{S}}=((0.03 * 0.35)+(0.04 * 0.25)) / 0.4=0.051
$$

or 5.1 percent over the decade. This would suggest that splintering may have added about $1 / 2$ percentage point to annual services growth during the $1980 \mathrm{~s}$.

Since the latest input-output matrix for India is available only for 1993-94, data for the 1990s are only partial. However, a similar calculation for the period 1989/90-1993/94 yields a splintering effect on annual services growth of about $1 / 4$ percentage point. Thus the increase in the use of services inputs is much less during early 1990s than in the 1980s. We do not yet know whether this trend continued for the rest of the decade. However, it has already been seen that some of the fastest growing services activities in the 1990s were oriented toward final consumption (e.g., community services, communication services, and hotels and restaurants), and this would be consistent with splintering having played a less important role in boosting growth in the 1990s. Overall, thus, increases in the use of services input in other sectors over time may be partly responsible for the increase in services share in GDP. However, the changes in input usage do not appear to have accelerated in the 1990s and thus cannot explain the recent pick-up in services growth.

\section{B. Role of Elastic Final Demand}

How important a role has increasing final demand played in boosting services growth? First, the share of services in private final consumption expenditure has almost tripled since 1951 (Table 7). The available data do not permit a precise split of private final consumption expenditure into a goods and a services component. Nonetheless, a rough estimate can be made, which indicates a sharp rise in the growth of final demand for services in the 1990s. That is, final consumption of services grew at a rate broadly similar to services output in the 1990s (Table 8), whereas in the 1980s, final consumption of services grew at a slower 
rate (this is consistent with the observation that there may have been more splintering during the 1980s).

Another way of trying to understand how large a role could have been played by final demand is to examine the behavior of services output as a share of GDP. Figure 7 shows that the share in GDP of most services activities, fast as well as trend growers, has been increasing over time, which can best be described by a positive linear trend and consistent with the income elasticity of final demand for services being greater than one. However, the fast growers also exhibit a sharp increase in the ratio of output to GDP from the early 1990s. For increases in final demand to explain this rapid growth would imply huge increases in the elasticities of final demand for these activities, but there is no prior reason to expect this kind of behavioral change.

Thus, there seem to be other factors at play besides splintering and income elasticity. In addition, if the growth in services output was largely a demand side phenomenon, we should not see a decline in the relative price of the services, as we do in the data. Figure 8 shows that the fast growing sub-sectors were characterized by declining prices, which suggests the growth of supply outpaced demand, or productivity in these services increased. By contrast, prices in the trend growing sub-sectors rose faster than the GDP deflator (not shown here), which supports the theory that a different mix of supply and demand factors were at work here than in the case of the fast growers.

\section{Role of Foreign Demand}

With the advent of the IT revolution, it has become possible to deliver services over long distances at a reasonable cost, thus trade in services has increased worldwide. India has been a particular beneficiary of this trend. In India, exports of services (in U.S. dollars) grew by an average of 15 percent a year in the 1990s, compared with 9 percent in the 1980s. Cumulatively, services exports increased fourfold in the 1990s and reached US\$25 billion in 2002 (about US\$7.5 billion of which was software exports). Services exports from India now exceed 1 percent of the global exports in services (see Salgado, 2003 and Figure 9). The increase in services exports has been most dramatic in software and other business services (included in miscellaneous services), but there has also been growth in the export of transport and travel services. As a result, the composition of services has changed dramatically in favor of miscellaneous services (Figure 10).

In order to make a rough estimate of the contribution of services exports to growth, we need to first estimate the value added component of exports. For this, we assume that input usage is same for services exports as for other services. From the input-output matrix, the input usage in services is roughly about 40 percent of gross output. Thus, about 60 percent of services exports would be valued added. Assuming that this percentage remained broadly similar over time, we calculate the value added by services exports and its contribution to growth of the sector for each year in the 1980s and the 1990s. The contribution of exports to annual average services growth is calculated to be about 0.2 percentage points and 
0.6 percentage points in the 1980s and the 1990s, respectively. Even though this contribution is fairly small, services exports have continued to grow rapidly in the current decade, with the growth of software exports averaging nearly 40 percent per annum during 2000-03. With the IT sector expected to continue to flourish in the future, its contribution to growth will become increasingly significant over time.

\section{Role of Liberalization}

Policy changes are also likely to be a factor behind the growth in services sector activity in India, especially changes relating to deregulation, the liberalization of FDI, and the privatization of government-owned services. ${ }^{11}$ An example would be the telecommunications industry where inefficient provision of services by the government led to a situation of effective rationing of services until the early 1990s. As seen earlier, communications as a whole has been one of the fastest growing services sub-sectors in the 1990s, and liberalization undoubtedly played a major role.

In order to empirically test the relationships between services growth and liberalization measures, an index of liberalization is needed. Such an index is difficult to create using the available information. Nonetheless, preliminary evidence of the effect of reform-related measures on services growth is provided by analyzing the correlation between the flow of FDI and the increase in private sector participation in services to sector growth. The relationship between the cumulative flow of FDI and services growth in the 1990s performance is found to be quite strong (even though this information is available only at a highly aggregated level, and the direction of causation is not clear a priori). The positive and significant association, as shown in Figure 11, holds even if we exclude the fastest growing communications sector. Similarly, the participation of the private sector in services activities also increased in the 1990s (for some activities, the share started increasing in the 1980s), as shown in Figure 12. ${ }^{12}$ The relationship is likely to be stronger if we include business services, for which the data on private and public shares are not available, but most of which originates in the private sector.

\footnotetext{
${ }^{11}$ Technically, it is the relative speed of liberalization that counts - service activity can be stimulated by rapid deregulation of services or by slow liberalization of other sectors, such as industry.

${ }^{12}$ Joshi (2002) examines the relationship between overall growth and the private and public shares of investment and GDP since the 1960s. He notes that there has been a significant increase in the share of investment by the private sector during the $1990 \mathrm{~s}$, and this has been matched by a faster growth of the services output originating in the private sector.
} 


\section{E. Quantifying the Contribution of Different Factors in Services Growth}

As the discussion above shows, many different factors played a role in explaining the growth of services in the 1990s, which we now attempt to estimate. We first estimate the trend part of the growth rates (which could be attributed to income elasticity and splintering effects). For this, we estimate the trend rate at which various services activities as a share of GDP increased up until 1990. We use this estimate to predict the size of the services sector during the 1990s. High income elasticity and splintering effects (unless the elasticities or the inputoutput coefficients change dramatically) would imply an increase in the share of services in GDP at a predetermined rate, but at one which is not likely to change much over time. We compare the actual share of services in GDP with our predicted share and calculate the difference. This residual (or excess) growth, which is positive for the fast growing sectors, cannot be attributed solely to elasticity and splintering effects, and therefore reflects other factors such as increased exports, policy reforms and technological progress. ${ }^{13}$

As illustrated by Figure 13, the residual component of growth in fast growers on average accounted for $13 / 4$ percentage points of growth of the services sector in the 1990s. The next step is to net out from the residual growth, the amount of growth attributed to increased exports of services in the $1990 \mathrm{~s}$. This we estimate at about $1 / 2$ percentage points. The remaining growth, or about $1 \frac{1 / 4}{4}$ percentage points, can thus be attributed to factors such as reforms.

\section{EMPIRICAL TeSTS OF COMPETING HyPOTHESES}

Taking a different approach from the previous section, we empirically test for the significance of different factors in explaining growth. We estimate regression equations separately using time series data for each activity, and then pooled data for various activities. The right hand side variables in the regressions include measures of income, variations in input coefficients, trade in goods and services, and a measure of policy changes. Reasonable proxies are available for most of these variables, but constructing a satisfactory measure of policy changes in each subsector did not prove feasible. ${ }^{14}$ We use two alternatives involving dummy variables in order to circumvent this limitation. ${ }^{15}$

\footnotetext{
${ }^{13}$ By definition, we find that trend growers do not exhibit any residual growth. The entire growth in these activities is attributed to elasticity and splintering effects.

${ }^{14}$ A more precise way to account for the effect of reforms in services would have been to create separate indices for liberalization in the industry, external sector, and the services sector. However, since usually more than one type of reforms was carried out in a particular year, so it not possible to create separate dummies for liberalization in different sectors.

${ }^{15}$ Using simple dummy variables is a very crude way to proxy reforms. They have the limitations that the dummies cannot be used to isolate the effects on growth of reforms or other events that might
}

(continued...) 
First, we estimate separate regression equations using time series data to explain growth in each services activity. To capture the influence of reforms, we use a dummy variable for the 1990s. The justification for such a dummy is that reforms in the services sector were mostly carried out in the 1990s. After controlling for other effects, a significant coefficient for this dummy would indicate that there is an unexplained part of growth which could possibly be attributed to reforms

The other approach we take is to use panel data for different service activities, where the observations are averaged over five-year periods. Instead of a general dummy for the 1990s, we construct a dummy variable which assigns a value 1 to activities that were liberalized in the periods 1986-90, 1991-95, and 1996-2000. However, this is only a marginal improvement over the previous approach, even so, the results are interesting as described below.

\section{A. Decade-Specific Dummies (Time Series Regressions)}

For decade-specific dummies, we use a time series regression to estimate the following equation:

$$
\begin{array}{r}
\mathrm{GSER}_{t}^{i}=\mathrm{C}^{i}+\alpha{ }^{i} \mathrm{GCDTY}_{t}+\beta{ }^{i} \mathrm{GTRD}_{t}+\gamma^{i} \mathrm{GEXS}_{t}+\delta^{i} \mathrm{D} 80+\lambda^{i} \mathrm{D} 90+\varepsilon^{i}{ }_{t} \\
t=1952 \ldots . .2000 \\
\varepsilon^{i} \approx N\left(\mathrm{O}, \sigma^{2 i}\right.
\end{array}
$$

The dependent variable in (3) is the annual growth rate in the $i$-th services activity in year $t$. The right hand side variables include the growth rates of (i) the commodity producing sectors (GCDTY), (ii) the volume of the external trade of goods (GTRD), and (iii) the value of exports in services (GEXS). To smooth out the noise in the annual data, all growth rates are measured as three-year moving averages. GCDTY is intended to capture the effect of income growth on final demand, as well as the effect of growth in other sectors on the demand for services inputs. GTRD is included to see whether increased openness of the economy to external trade has also resulted in higher growth for services. This link is expected to be important a priori for distribution services, transport, and hotels and restaurants. Finally, since certain sectors (especially business services and hotels and restaurants) are highly dependent on foreign demand, we include GEXS in the regressions. In order to account for any residual in growth, we also have separate dummies for the 1980s and 1990s.

The equations are estimated using ordinary least squares. Regression results reported in Table 9 show that for each fast growing sub-sector, the dummy for the 1990s is positive and highly significant. The demand side factors seem relatively less important in explaining growth in these activities, as their coefficients are mostly insignificant. The one exception is

have been happening in the 1990s. In addition, these dummies do not precisely capture the timing of the reforms, and finally, measure the extent or intensity of reforms. 
GEXS, which, unsurprisingly, has a positive and significant coefficient in the equation for business services (that is, IT). By contrast, in the equations for trend growing activities, at least one of the demand side variables has a significant coefficient. Another contrast is that the dummy for the 1990s is not significant in explaining the growth in most of the activities that grew at trend rates in the 1990s. The results also show that the dummy for the 1980s is significant for business, banking, and community services. For banking services, this could be due to the deregulation that began in the 1980s. For business services, the IT sector was almost nonexistent in the 1980s, so the growth is perhaps due to other activities included here. As expected, growth in commodity producing sectors and in the volume of external trade in goods are both important in explaining the growth in distribution services.

We considered two modifications in the regressions above. First, in order to capture the income effect on the growth of services demand, we include the growth rate of GDP (GGDP), rather than that of the commodity producing sectors. Second, we include separate dummies for the first and second half of the 1990s. The rationale for doing this is that some of the major reforms in the services sector were not carried out until the mid-1990s and may have affected growth more in the second half of the decade than in the first half. The results for the equation using GGDP are stronger, with its estimated coefficient larger and more significant for most activities, which is not surprising. Even with this variable, the significance of the dummy for the 1990s is retained. As expected, the results are also found to be stronger for the dummy for the second half of the 1990s than for the first half.

\section{B. Sector-Specific Liberalization Dummies (Panel Data Regressions)}

Using panel data regressions, we estimate the following equation controlling for fixed effects (which allows for intercepts to vary over different units).

$$
\mathrm{GSER}_{i t}=\mathrm{C}_{i}+\alpha \mathrm{GIND}_{i t}+\beta \mathrm{GAGR}_{i t}+\eta \mathrm{GTG}_{i t}+\gamma \mathrm{GTS}_{i t}+\delta \mathrm{DSER}_{i t}+\varepsilon_{i t}
$$

The regressions are estimated for the following services activities: trade, hotels, rail transport, transport by other means, storage, communications, insurance, and as well as dwellings, business, community, banking, legal, and personal services. The time period used is 1970-2000, and the observations are averaged over the 1970s, 1981-85, 1986-90, 199195, and 1996-2000. The dependent variable is average annual growth rate in services activity $i$ in period $t$. The right hand side variables are average growth rates in (i) industry (GIND) and agriculture (GAGR), (ii) the volume of external trade in goods (GTG), and (iii) the value of exports of services (GTS) in period $t$. A dummy variable (DSER) measures whether reforms were carried out in each services sub-sector.

The variable which is found to be the most significant is the dummy variable for reform measures in each activity. Thus, the sectors that were opened up for FDI, external trade, or private ownership, etc. were the ones which experienced faster growth. Among other variables, we find services growth to be significantly correlated with the growth in the 
industrial sector. As a robustness test, we check whether the dummy for the 1990s (D90s) yields a significant coefficient after controlling for the reform-specific dummy. Results in Column II of Table 10 show that the coefficient for D90s is no longer significant. Thus, we argue that the acceleration of the 1990s is likely due to reforms and that this variable is an important determinant of the higher growth during that decade.

\section{SUMMARY AND CONCLUSION}

This paper studies the growth of the services sector in India. It shows that in common with the experience of many other countries, the services sector in India has grown faster than agriculture and industry. As a result, the share of services in GDP has increased over time. In the 1990s, services growth was particularly strong, and this has led to the services share in output being relatively large in India compared with other countries at similar levels of development. What is also striking about India's growth experience is that the services sector does not appear to have created many jobs. Admittedly the employment data suffer from limitations. Nonetheless, unlike the experience of many countries where productivity growth in the service economy has tended to lag behind that of other sectors, it appears that the Indian services sector has been characterized as experiencing increasing labor productivity.

The acceleration in growth of the services sector in India in the 1990s was due to fast growth in communications, banking services, business services (IT), and community services (education and health). The remaining sectors grew at a constant or trend growth rate. We show that factors such as high income elasticity of demand and increased input usage of services by other sectors have played an important part in elevating services growth. Also important, at least in the 1990s, have been factors such as economic reforms and the growth in foreign demand for services exports. Significant productivity gains appear to have occurred in the faster growing sectors, leading to a decline in their relative prices.

Our findings suggest that there is considerable scope for further rapid growth in India's service economy. That Indian services exports have strong future growth prospects is well known, but we also find that there is considerable scope for further rapid growth in other segments provided that deregulation of the services sector continues. Nevertheless, it is imperative that the industrial and agricultural sectors also grow rapidly. The relatively jobless nature of growth in India's services sector further underscores this need. 


\section{References}

Acharya, Shankar, 2002a, "India's Medium-Term Growth Prospects," Economic and Political Weekly, July 13, pp. 2897-06.

— 2002b, "Macroeconomic Management in the 1990s," Economic and Political Weekly, 37 (16), April 20, pp. 1515-38.

— 2003, "What's Happening in Services," Business Standard, December 23.

Bhagwati, Jagdish, 1984, "Splintering and Disembodiment of Services and Developing Nations," World Economy, Vol. 7, No. 2, pp. 133-43.

Bhattacharya, B.B., and Arup Mitra, 1990, "Excess Growth of Tertiary Sector in Indian Economy, Issues and Implications," Economic and Political Weekly, November 3, pp. 2445-50.

Chenery, Hollis, B. 1960, "Patterns of Industrial Growth," American Economic Review, Vol. 57, pp. 415-26.

— Over Time," Review of Economics and Statistics, Vol. 50, pp. 391-416.

Echevarria, Cristina, 1997, "Changing Sectoral Composition Associated with Economic Growth," International Economic Review, Vol. 38, pp. 431-52.

Francois, Joseph, F., and Kenneth A. Reinhart, 1996, "The Role of Services in the Structure of Production and Trade: Some Stylized Facts from a Cross-Country Analysis," Asia-Pacific Economic Review, Vol. 2 (May), pp. 1-9.

Hansda, Sanjay Kumar, 2002a, "Services Sector in the Indian Economy: A Status Report," RBI Staff Studies, Department of Economic Analysis and Policy (New Delhi: Reserve Bank of India).

$\longrightarrow, 2002 b$, "Sustainability of Services and Services-Led Growth: An Input Output Exploration of the Indian Economy," RBI Papers (New Delhi: Reserve Bank of India).

Inman, Robert P., 1985, "Introduction and Overview," in Managing the Service Economy: Prospects and Problems (Cambridge: Cambridge Univ. Press). 
Joshi, Dharmakirti, 2002, “The Public Private Balance: A Macro View," Discussion Paper Series, (New Delhi: Crisil Center for Economic Research).

Kongsamut, Piyabha, Sergio Rebelo, and Danyang Xie, 2001, "Beyond Balanced Growth," IMF Working Paper, 01/85 (Washington: International Monetary Fund).

Kravis, Irving B. 1985, "Services in World Transactions," in Managing the Service Economy: Prospects and Problems, ed. By Robert P. Inman (Cambridge: Cambridge University Press).

Mattoo, Aaditya, Deepak Mishra, and Anirudh Shinghal, 2003, "Trade in Services: Access to Foreign Markets, Domestic Reform and International Negotiations," (unpublished; Washington: World Bank).

Reserve Bank of India, 2002, Report on Currency and Finance, (Mumbai: Reserve Bank of India.

Salgado, Ranil, 2003, “India's Global Integration and The Role of the IT Sector," IndiaSelected Issues Washington: International Monetary Fund.

Sastry, D.V.S., Balwant Singh, Kaushik Bhattacharya, and N.K. Unnikrishnan, 2003, "Sectoral Linkages and Growth Prospects: Some Reflections on the Indian Economy," Economic and Political Weekly, June 14, pp. 2390-2397

Slifman, L., and C. Corrado, 1996, "Decomposition of Productivity and Unit Costs," (unpublished; Washington: Board of Governors of the Federal Reserve System).

Virmani, Arvind, 2002, "Bhartiya Rate of Growth: The Role of Services, Planning Commission (New Delhi: Government of India). 
Figure 1. India: Sectoral Shares in GDP, 1950-2000

Sectoral Shares in GDP

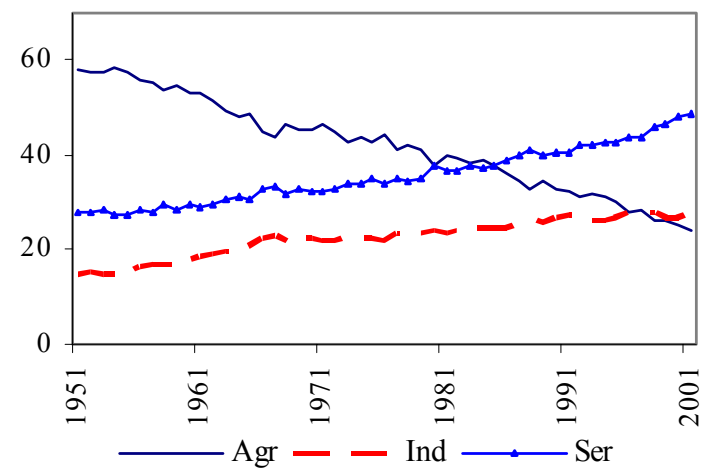

Change in Sectoral Shares

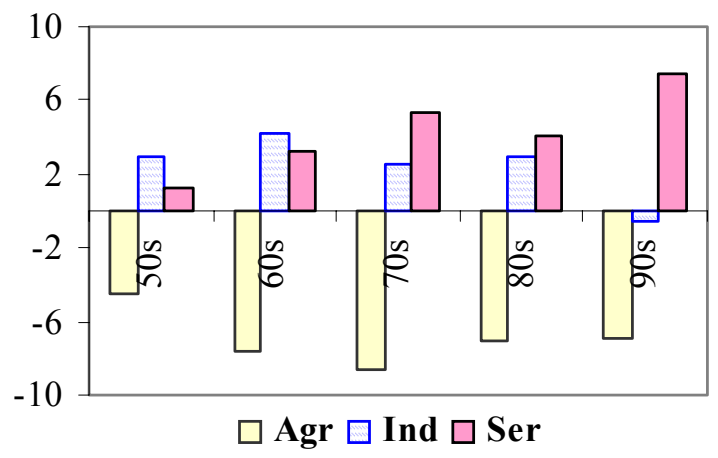

Source: CSO.

Figure 2: Cross Country Data on Per Capita Income and Share of Services in GDP

Per Capita Income and Services Share in GDP (1990)

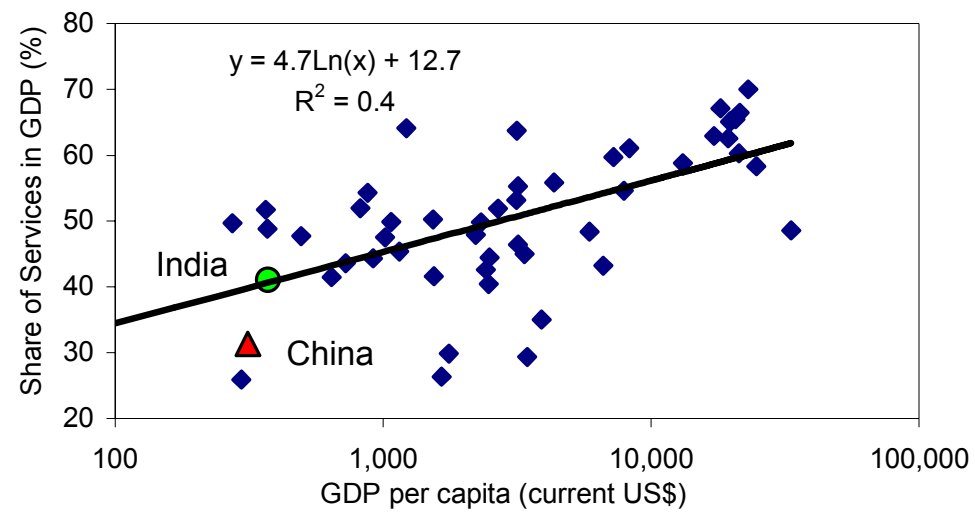

Per Capita income and Services Share in GDP (2001)

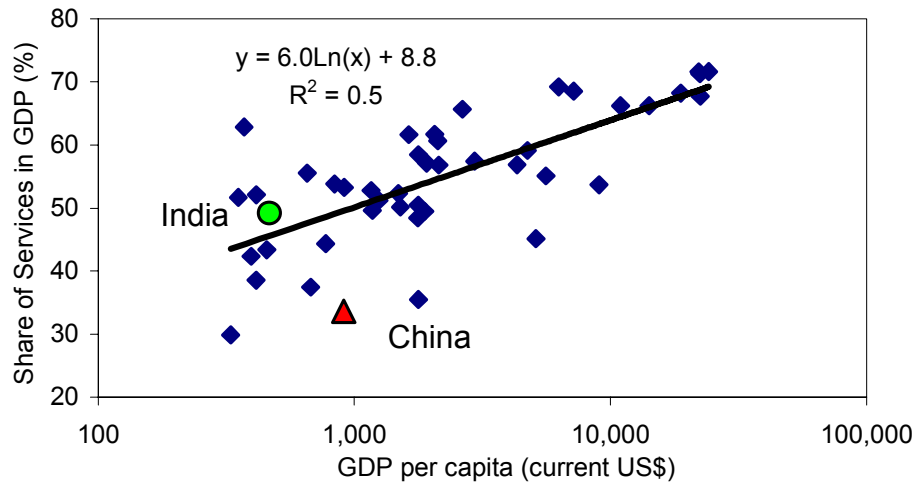

Source: WDI. 
Figure 3: Service Output vs. Employment Shares in 2001

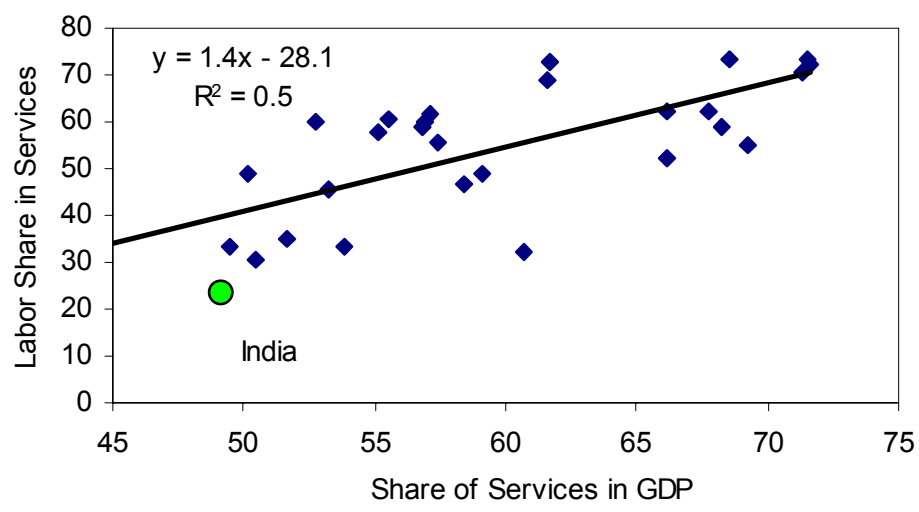

Source: WDI.

Figure 4: Growth Rate of Services Sector in India

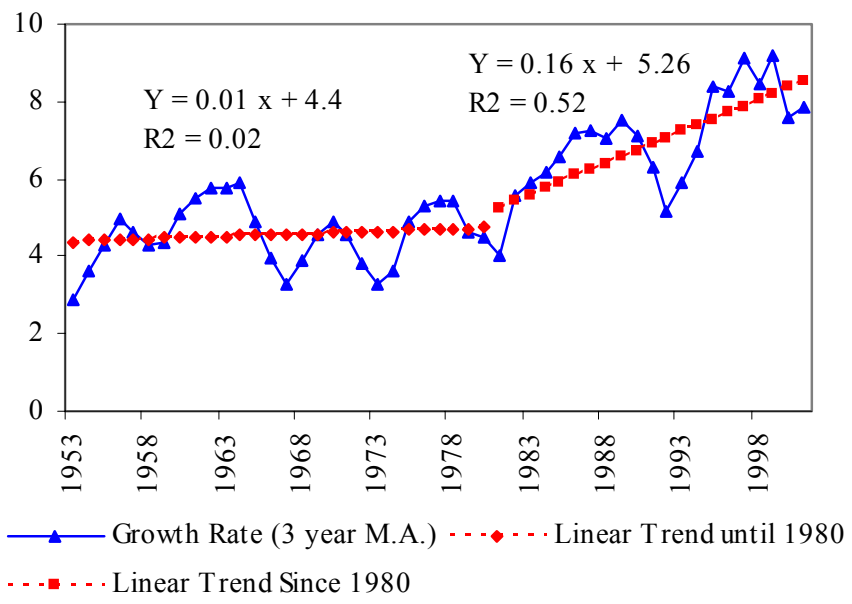

Source: Authors' estimates using CSO data. 
Figure 5: Fast Growing Services Segments in India (Three-year moving average)
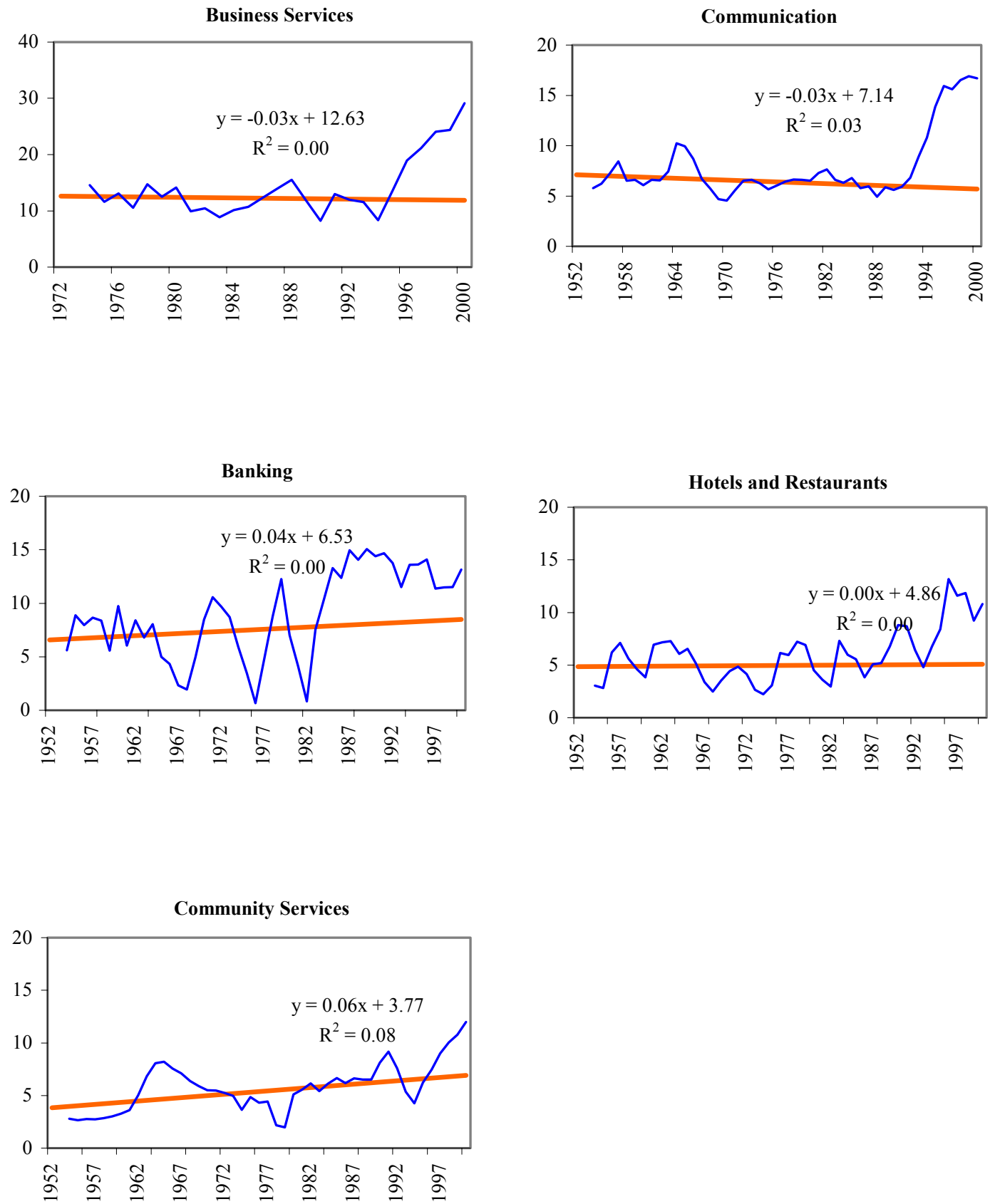

Source: Authors' estimates using CSO data. 
Figure 6: Contribution of Fast and Trend Growers to Growth in Services ${ }^{1}$
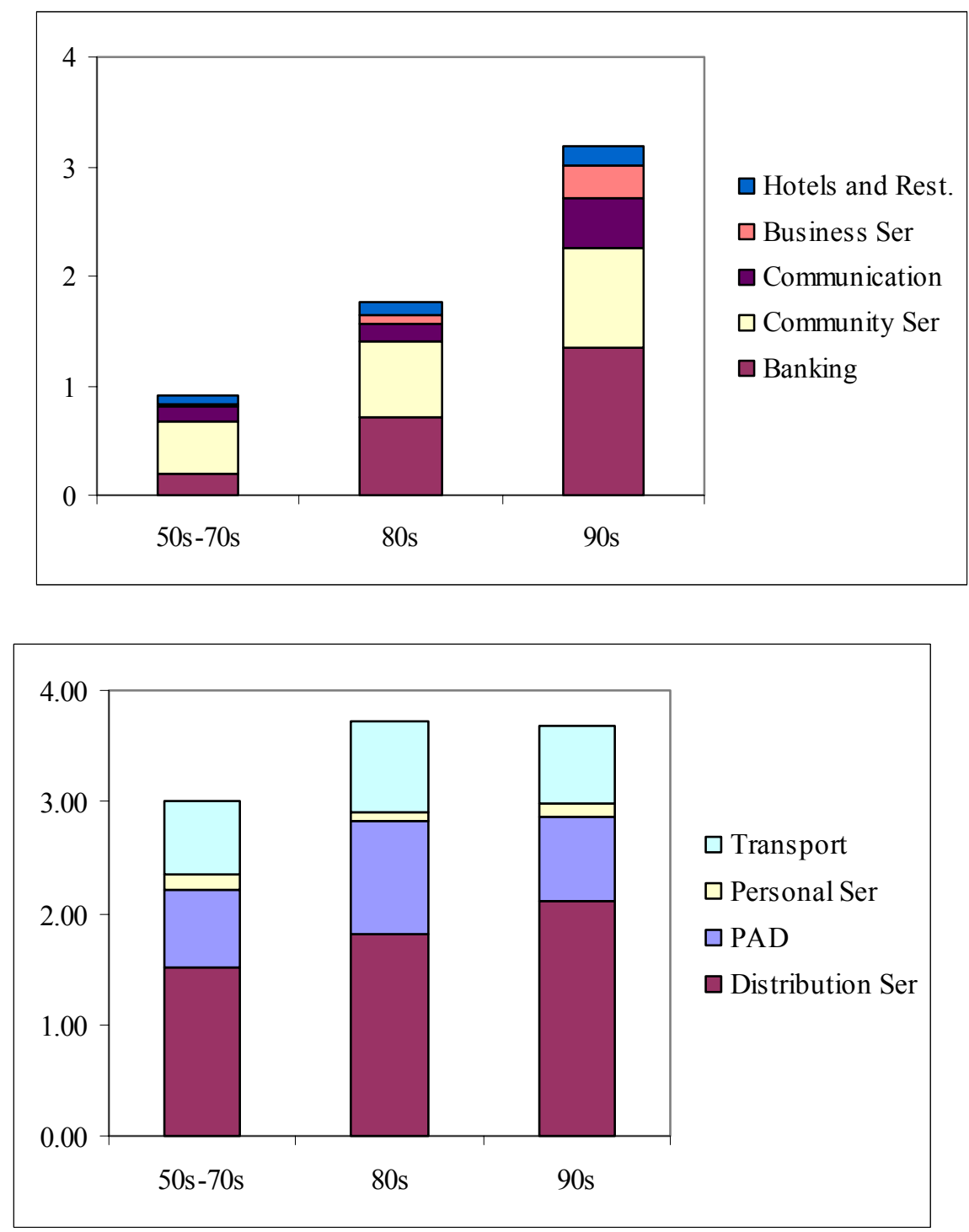

Source: Authors' calculations using CSO data.

1/ Figure 6 does not include the contribution of railways, legal services, storage, real estate, and other services. Hence the total contribution shown does not add up to the total growth of the services sector. 
Figure 7: Output of Fast Growers as Percentage of GDP

(Linear time trend was estimated using data up to 1990, for banking data up to 1980 was used)
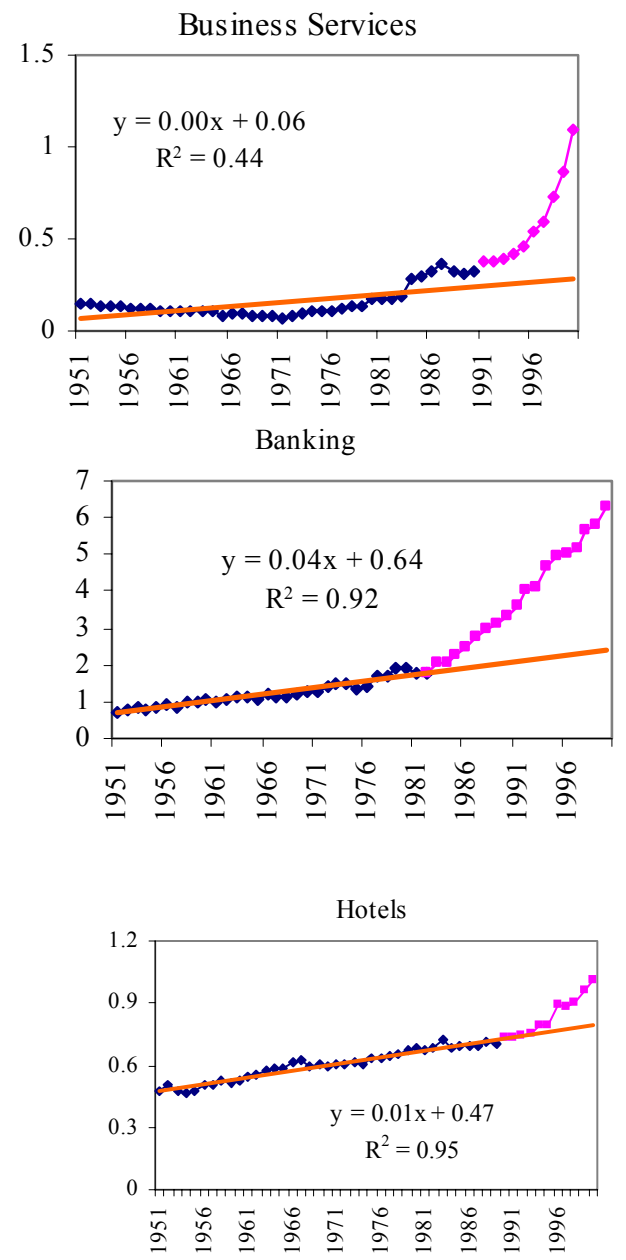

Source: Authors' estimates using CSO data.

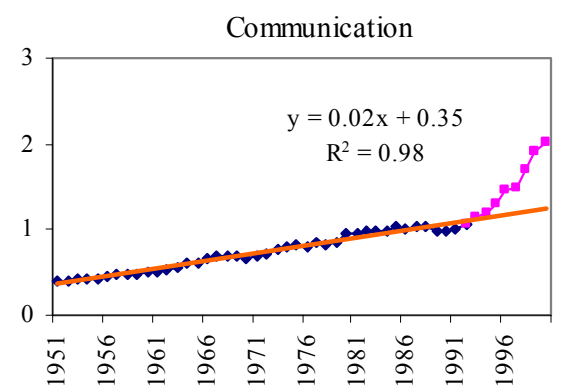

Community Services

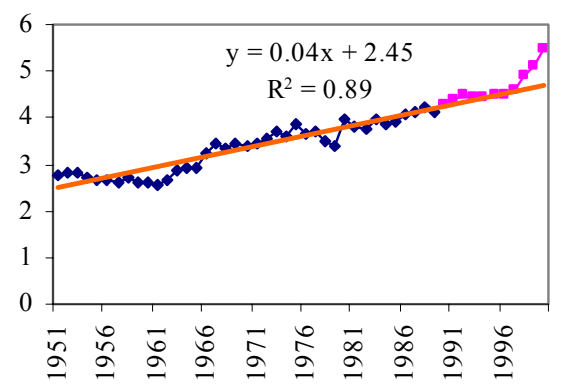


Figure 8: Price Deflator of Services Relative to the GDP Deflator

(Index, 1991 = 100; for Business Services and Banking, Index, 1980=100)
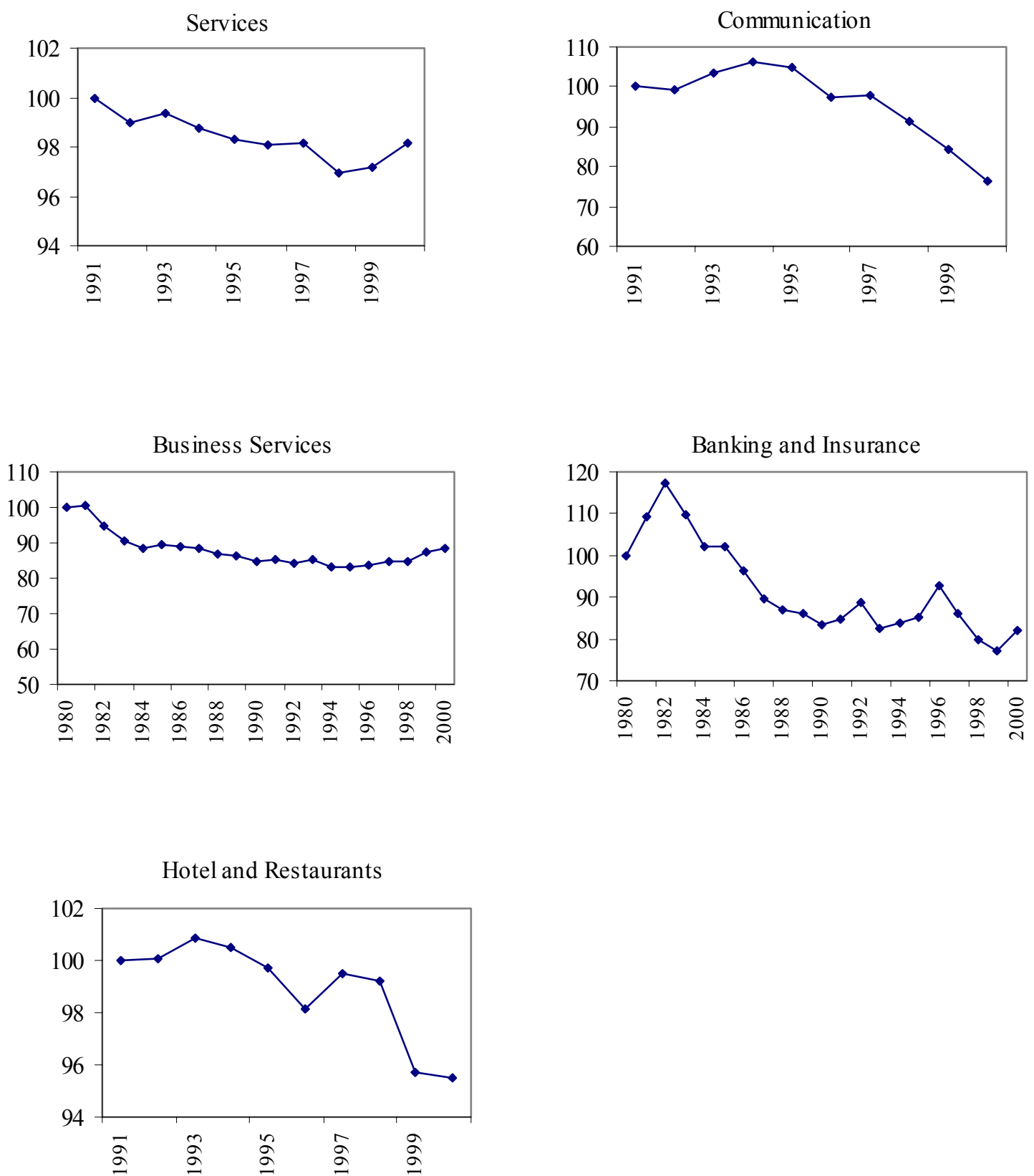

Source: Authors' estimates using CSO data. 


\section{Figure 9: Indian Services Exports}
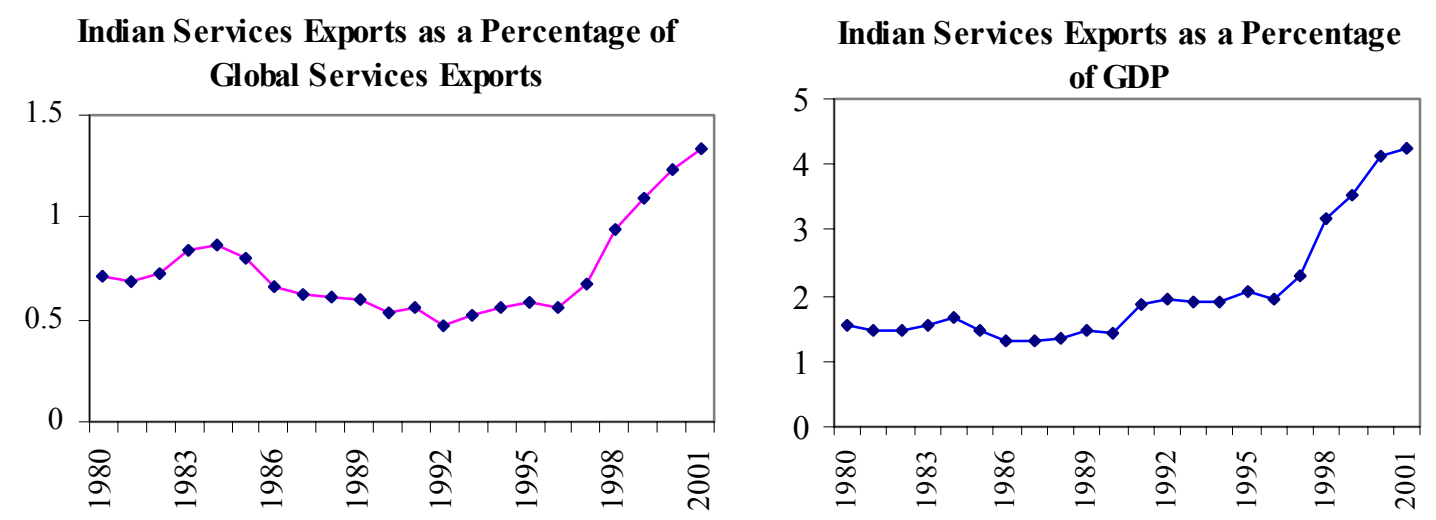

Source: Salgado (2003).

\section{Figure 10: Composition of Services Exports from India}

1990

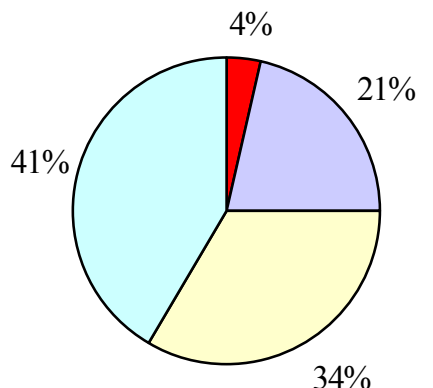

$\square$ Other $\square$ transport $\square$ travel $\square$ Miscellaneous
2000

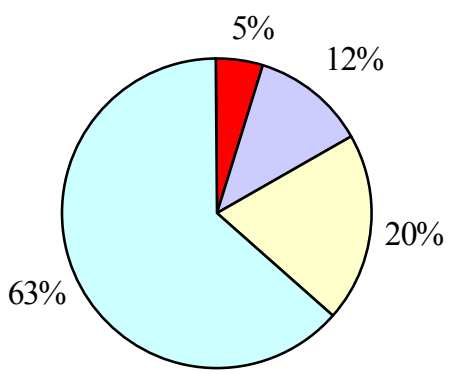

$\square$ Other $\square$ transport $\square$ travel $\square$ Miscellaneous

Source: RBI. 
Figure 11: Cumulative FDI in the 1990s and Average Growth

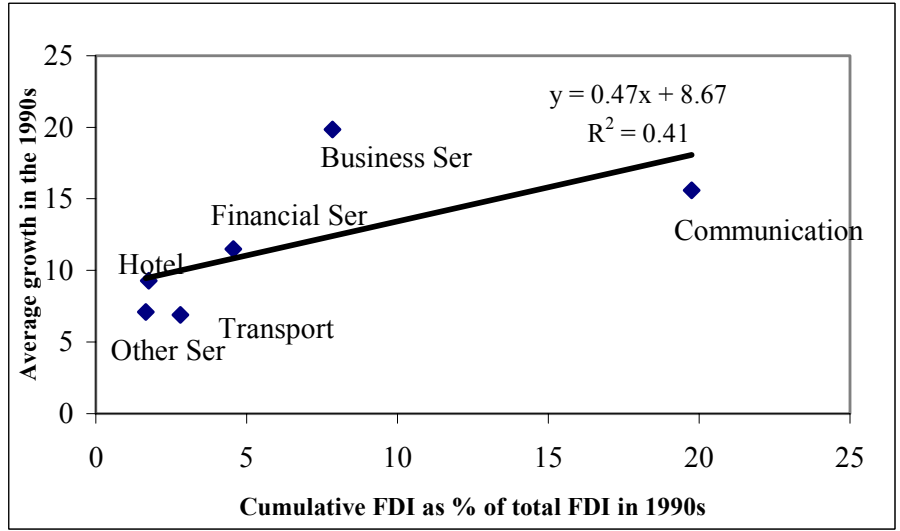

Source: Authors' estimates using CSO data.

Figure 12: Increase in the Private Sector's Share and Average Growth

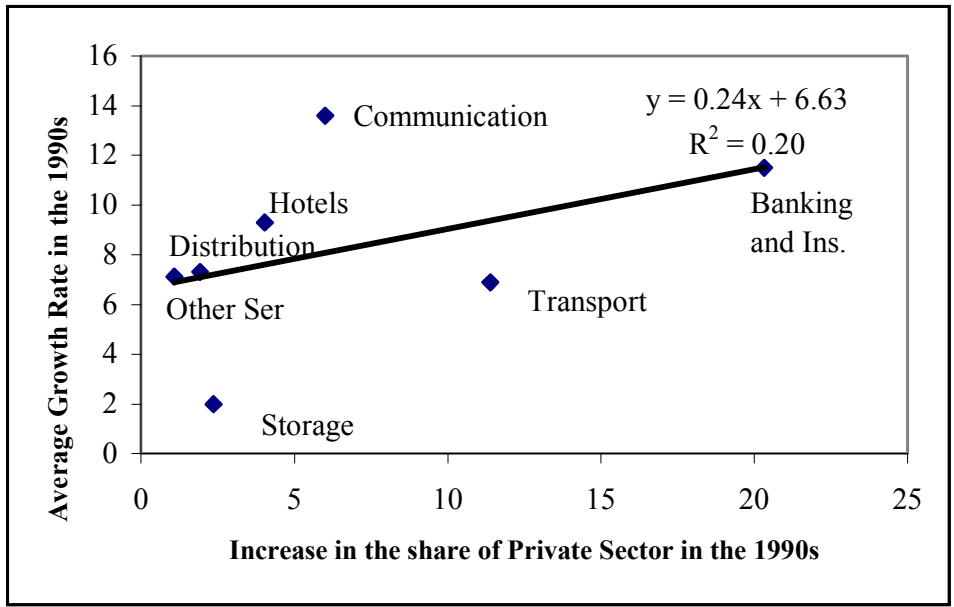

Source: Authors' estimates using CSO data.

Figure 13: Contribution of Different Factors in Explaining Growth in Services

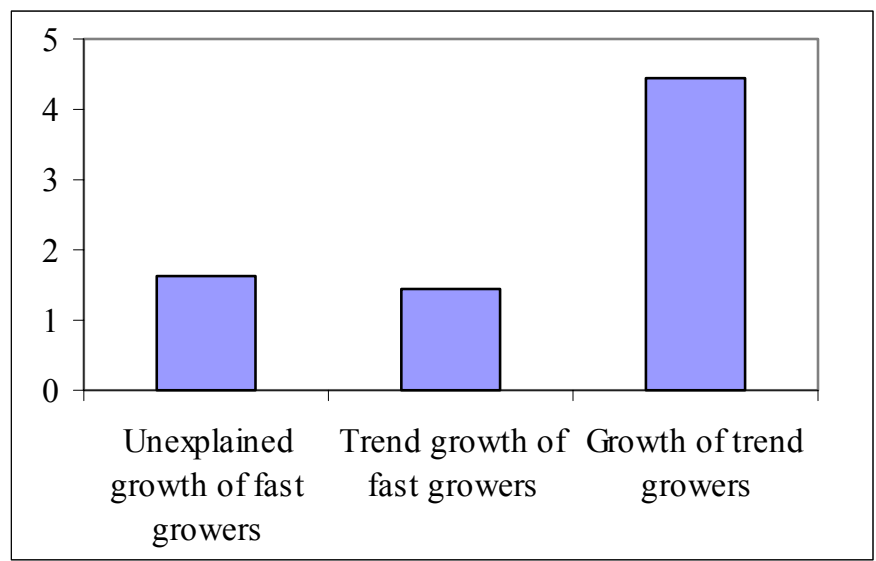

Source: Author's estimates using CSO data. 


\begin{tabular}{|c|c|c|c|}
\hline \multicolumn{4}{|c|}{$\begin{array}{c}\text { Table 1: Sectoral Growth Rates } \\
\text { Average growth } \\
\text { (In percent per annum) }\end{array}$} \\
\hline & $1951-1980$ & 1981-1990 & 1991-2000 \\
\hline Agriculture & 2.1 & 4.4 & 3.1 \\
\hline Industry & 5.3 & 6.8 & 5.8 \\
\hline Services & 4.5 & 6.6 & 7.5 \\
\hline GDP & 3.5 & 5.8 & 5.8 \\
\hline
\end{tabular}

\begin{tabular}{|c|c|c|c|c|}
\hline \multicolumn{5}{|c|}{$\begin{array}{l}\text { Table 2: Sectoral Shares in GDP in 2001, Global Averages } \\
\text { (Percent of GDP) }\end{array}$} \\
\hline & Agriculture & Industry & & Services \\
\hline Low income & 24 & 32 & 45 & Stage I \\
\hline Lower middle income & 12 & 40 & 48 & \\
\hline Upper middle income & 7 & 33 & 60 & Stage II \\
\hline High income & 2 & 29 & 70 & \\
\hline \multicolumn{5}{|c|}{$\begin{array}{l}\text { Source: World Bank’s WDI, 2003, Table 4.2. } \\
\text { Definition: Low income: per capita GDP }<\$ 745 \text {; Lower middle- } \$ 746-2,975 \text {; Upper middle- } \\
\$ 2,976-9,205 \text {; and high- }>\$ 9,206 \text {. }\end{array}$} \\
\hline
\end{tabular}




\begin{tabular}{|c|c|c|c|c|}
\hline & \multicolumn{4}{|c|}{$\begin{array}{l}\text { Table 3. India: Sectoral Shares in GDP, 1950-2003 } \\
\text { (Percent of GDP) }\end{array}$} \\
\hline & Agriculture & Industry & & ervices \\
\hline 1950 & 58 & 15 & 28 & \\
\hline 1980 & 38 & 24 & 38 & Stage I \\
\hline 1990 & 33 & 27 & 41 & \\
\hline 2000 & 24 & 27 & 49 & Stage II \\
\hline $2003^{\#}$ & 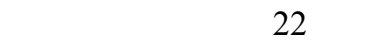 & 27 & 51 & \\
\hline
\end{tabular}

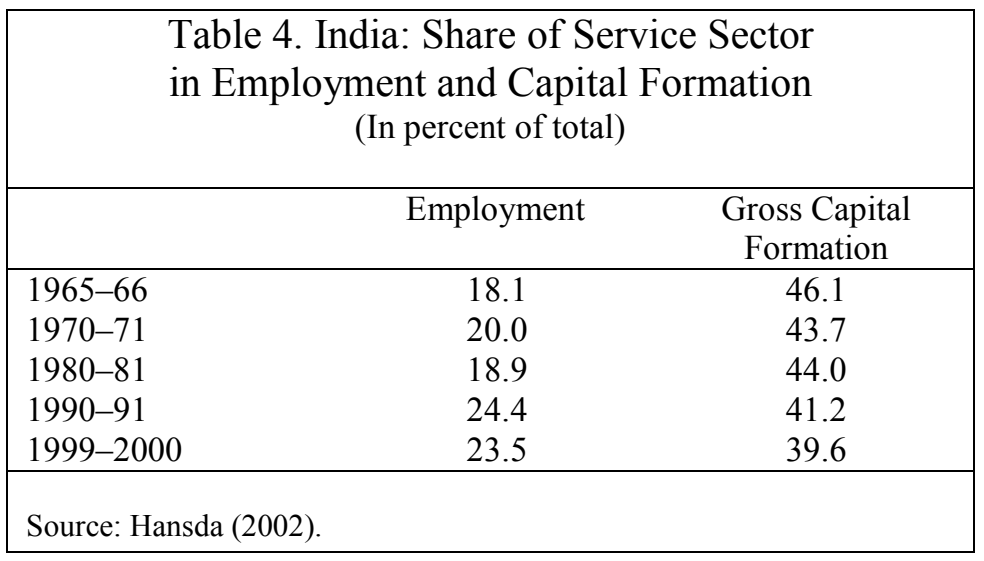


Table 5: Growth Rates and Sectoral Shares

\begin{tabular}{|c|c|c|c|c|}
\hline Sector & Activities Included & $\begin{array}{l}\text { Avg. Growth in } \\
\text { 50s-70s } \\
\text { (Share in GDP } \\
\text { in 1980) } \\
\end{array}$ & $\begin{array}{l}\text { Avg. Growth } \\
\text { in 80s } \\
\text { (Share in GDP } \\
\text { in 1990) }\end{array}$ & $\begin{array}{l}\text { Avg. Growth } \\
\text { in } 90 \mathrm{~s} \\
\text { (Share in } \\
\text { GDP in 2000) }\end{array}$ \\
\hline \multicolumn{5}{|c|}{ Trade, hotels and restaurant } \\
\hline $\begin{array}{l}\text { Trade (distribution } \\
\text { services) }\end{array}$ & $\begin{array}{l}\text { Wholesale and retail trade in commodities } \\
\text { both produced at home (including exports) and } \\
\text { imported, purchase and selling agents, } \\
\text { brokers and auctioneers }\end{array}$ & $\begin{array}{c}4.8 \\
(11.7)\end{array}$ & $\begin{array}{c}5.9 \\
(11.9)\end{array}$ & $\begin{array}{c}7.3 \\
(13.7)\end{array}$ \\
\hline Hotels \& Restaurants & $\begin{array}{l}\text { Services rendered by hotels and other lodging } \\
\text { places, restaurants, cafes and other eating and } \\
\text { drinking places }\end{array}$ & $\begin{array}{c}4.8 \\
(0.7)\end{array}$ & $\begin{array}{c}6.5 \\
(0.7)\end{array}$ & $\begin{array}{c}9.3 \\
(1.0)\end{array}$ \\
\hline \multicolumn{5}{|c|}{ Transport, storage and communication } \\
\hline Railways & & $\begin{array}{c}4.2 \\
(1.5)\end{array}$ & $\begin{array}{c}4.5 \\
(1.4)\end{array}$ & $\begin{array}{c}3.6 \\
(1.1)\end{array}$ \\
\hline $\begin{array}{l}\text { Transport by other } \\
\text { means }\end{array}$ & $\begin{array}{l}\text { Road, water, air transport, services incidental } \\
\text { to transport }\end{array}$ & $\begin{array}{c}6.3 \\
(3.6)\end{array}$ & $\begin{array}{c}6.3 \\
(3.8)\end{array}$ & $\begin{array}{c}6.9 \\
(4.3)\end{array}$ \\
\hline Storage & & $\begin{array}{c}5.5 \\
(0.1)\end{array}$ & $\begin{array}{c}2.7 \\
(0.1)\end{array}$ & $\begin{array}{c}2 \\
(0.1)\end{array}$ \\
\hline Communication & $\begin{array}{l}\text { Postal, money orders, telegrams, telephones, } \\
\text { overseas communication services, } \\
\text { miscellaneous }\end{array}$ & $\begin{array}{c}6.7 \\
(1.0)\end{array}$ & $\begin{array}{c}6.1 \\
(1.0)\end{array}$ & $\begin{array}{l}13.6 \\
(2.0)\end{array}$ \\
\hline \multicolumn{5}{|c|}{ Financing, insurance, real estate and business services } \\
\hline Banking & $\begin{array}{l}\text { Banks, banking department of RBI, post office } \\
\text { saving bank, nonbank financial institution, } \\
\text { cooperative credit societies, employees } \\
\text { provident fund }\end{array}$ & $\begin{array}{c}7.2 \\
(1.9)\end{array}$ & $\begin{array}{l}11.9 \\
(3.4)\end{array}$ & $\begin{array}{l}12.7 \\
(6.3)\end{array}$ \\
\hline Insurance & Life, postal life, nonlife & $\begin{array}{c}7.1 \\
(0.5)\end{array}$ & $\begin{array}{l}10.9 \\
(0.8)\end{array}$ & $\begin{array}{c}6.7 \\
(0.7)\end{array}$ \\
\hline Dwellings, real estate & & $\begin{array}{l}2.6 \\
(4.0)\end{array}$ & $\begin{array}{c}7.7 \\
(4.8)\end{array}$ & $\begin{array}{c}5.0 \\
(4.5)\end{array}$ \\
\hline Business services & & $\begin{array}{c}4.2 \\
(0.2)\end{array}$ & $\begin{array}{l}13.5 \\
(0.3)\end{array}$ & $\begin{array}{l}19.8 \\
(1.1)\end{array}$ \\
\hline Legal services & & $\begin{array}{c}2.6 \\
(0.0)\end{array}$ & $\begin{array}{l}8.6 \\
(0.0)\end{array}$ & $\begin{array}{l}5.8 \\
(0.0)\end{array}$ \\
\hline \multicolumn{5}{|c|}{ Community, social and personal services } \\
\hline Public administration, & lefense & $\begin{array}{c}6.1 \\
(5.3)\end{array}$ & $\begin{array}{c}7.0 \\
(6.0)\end{array}$ & $\begin{array}{c}6.0 \\
(6.1)\end{array}$ \\
\hline Personal services & $\begin{array}{l}\text { Domestic, laundry, barber, beauty shops, } \\
\text { tailoring, others }\end{array}$ & $\begin{array}{c}1.7 \\
(1.6)\end{array}$ & $\begin{array}{c}2.4 \\
(1.1)\end{array}$ & $\begin{array}{c}5.0 \\
(1.1)\end{array}$ \\
\hline Community services & $\begin{array}{l}\text { Education, research, scientific, medical, } \\
\text { health, religious and other community }\end{array}$ & $\begin{array}{c}4.8 \\
(4.0)\end{array}$ & $\begin{array}{c}6.5 \\
(4.3)\end{array}$ & $\begin{array}{c}8.4 \\
(5.5)\end{array}$ \\
\hline Other services & $\begin{array}{l}\text { Recreation, entertainment, radio, TV } \\
\text { broadcast, sanitary services }\end{array}$ & $\begin{array}{c}3.4 \\
(1.1)\end{array}$ & $\begin{array}{c}5.3 \\
(1.0)\end{array}$ & $\begin{array}{l}7.1 \\
(0.7)\end{array}$ \\
\hline
\end{tabular}




\begin{tabular}{|c|c|c|c|}
\hline & ulture & Industry & Services \\
\hline \multicolumn{4}{|c|}{$1979-80$} \\
\hline Agriculture & 0.06 & 0.13 & 0.04 \\
\hline Industry & 0.07 & 0.35 & 0.11 \\
\hline \multicolumn{4}{|c|}{ 1989-90 } \\
\hline Agriculture & 0.17 & 0.04 & 0.04 \\
\hline Industry & 0.14 & 0.37 & 0.17 \\
\hline \multicolumn{4}{|c|}{ 1993-94 } \\
\hline Agriculture & 0.15 & 0.04 & 0.03 \\
\hline Industry & 0.14 & 0.37 & 0.15 \\
\hline Services & 0.05 & 0.21 & 0.20 \\
\hline
\end{tabular}

\begin{tabular}{|c|c|}
\hline \multicolumn{2}{|c|}{ Table 7: Private Final Consumption of Services } \\
in India \\
\hline Year & $\begin{array}{c}\text { Private Final Consumption } \\
\text { (percent of total final } \\
\text { consumption) }\end{array}$ \\
\hline 1950-51 & 10.2 \\
$1970-71$ & 13.4 \\
$1980-81$ & 15.5 \\
$1990-91$ & 20.4 \\
$1999-00$ & 27.6 \\
\hline
\end{tabular}

Table 8: Growth Rates of Value Added and Final Consumption of Services and GDP

\begin{tabular}{|cccc|}
\hline & $\begin{array}{r}\text { Private final } \\
\text { consumption of } \\
\text { services }\end{array}$ & $\begin{array}{c}\text { Service } \\
\text { sector value- } \\
\text { added }\end{array}$ & GDP \\
\hline $1970 \mathrm{~s}$ & 4.6 & 4.5 & 2.9 \\
$1980 \mathrm{~s}$ & 5.4 & 6.6 & 5.8 \\
$1990 \mathrm{~s}$ & 7.9 & 7.5 & 5.8 \\
\hline \multicolumn{4}{l}{ Source: Own estimates using CSO data. } \\
\hline
\end{tabular}




\begin{tabular}{|c|c|c|c|c|c|c|c|c|c|c|}
\hline 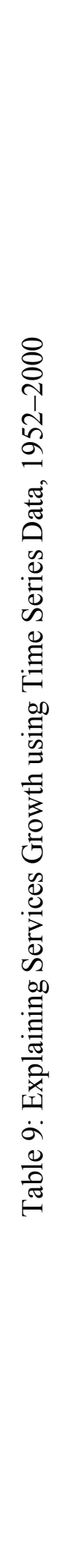 & 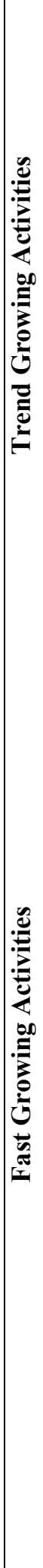 & 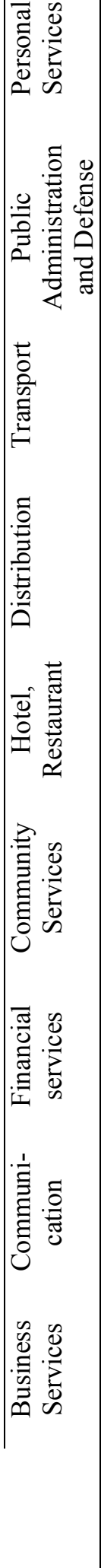 & 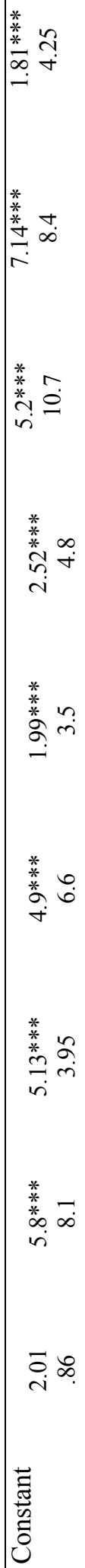 & $\simeq$ & $\stackrel{*}{*} \underset{*}{*} \tilde{c}$ & $8 \stackrel{m}{i}$ & 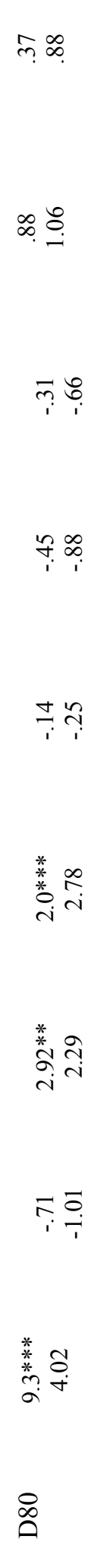 & 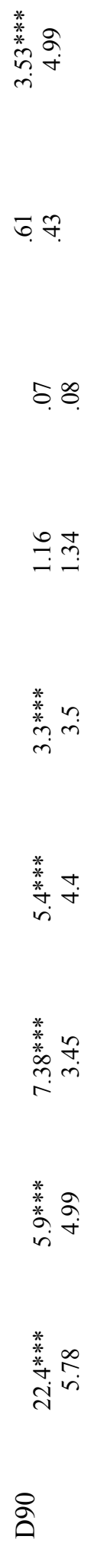 & $\approx$ & 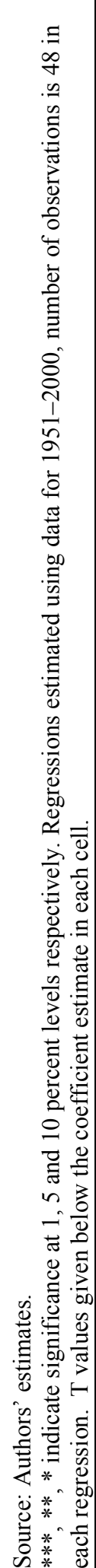 \\
\hline
\end{tabular}


Table 10. Explaining Services Growth using Panel Data, 1970-2000

\begin{tabular}{|c|c|c|}
\hline & $\mathbf{I}$ & II \\
\hline GAgr & $\begin{array}{l}.99 \\
1.1\end{array}$ & $\begin{array}{l}.07 \\
.20\end{array}$ \\
\hline GInd & $\begin{array}{l}1.33 * * \\
2.12\end{array}$ & $\begin{array}{l}.82 * \\
1.88\end{array}$ \\
\hline GTG & $\begin{array}{l}.45 \\
1.1\end{array}$ & \\
\hline GTS & $\begin{array}{c}.15^{*} \\
1.7\end{array}$ & $\begin{array}{l}.13 \\
1.5\end{array}$ \\
\hline DSer & $\begin{array}{c}5.7 * * * \\
3.6\end{array}$ & $\begin{array}{c}5.7 * * * \\
3.6\end{array}$ \\
\hline D90s & & $\begin{array}{l}-1.1 \\
-1.0\end{array}$ \\
\hline R2, adj. R2 & $.65, .53$ & $.65, .53$ \\
\hline $\begin{array}{l}\text { F test for equality of } \\
\text { intercept across units }\end{array}$ & $\begin{array}{l}2.8 \text { (F-Stat) } \\
.00 \text { (p value })\end{array}$ & $\begin{array}{l}2.8 \text { (F-Stat) } \\
.00 \text { (p value) }\end{array}$ \\
\hline \multicolumn{3}{|c|}{$\begin{array}{l}\text { Source: Authors' estimates. } \\
\text { Number of observations is } 65 \text { in each regression. } * * *, * *, * \text { indicate } \\
\text { significance at } 1,5 \text { and } 10 \text { percent levels respectively. T values given below the } \\
\text { coefficient estimate in each cell. }\end{array}$} \\
\hline
\end{tabular}


Sources of Data and Construction of Variables

\begin{tabular}{|c|c|c|}
\hline Variable Name & Construction of Variable ${ }^{1}$ & Source \\
\hline & Variables used in regression equation 1 & \\
\hline Grow $_{\mathrm{i}}$ & $\begin{array}{l}\text { Average growth rate of output in activity i during } \\
\text { the } 1990 \text { s. }\end{array}$ & $\begin{array}{l}\text { Own calculations using } \\
\text { CSO data }\end{array}$ \\
\hline GCDTY & $\begin{array}{l}3 \text { year moving average of growth rates in the } \\
\text { commodity producing sectors }\end{array}$ & $\begin{array}{l}\text { Own calculations using } \\
\text { CSO data }\end{array}$ \\
\hline Gtrade & $\begin{array}{l}3 \text { year moving average of growth of the volume of } \\
\text { external trade (exports }+ \text { imports) of goods. }\end{array}$ & $\begin{array}{l}\text { Own calculations using } \\
\text { data from RBI Bulletins }\end{array}$ \\
\hline GSerEx & 3 year moving average of growth of services exports. & $\begin{array}{l}\text { Own calculations using } \\
\text { data from RBI Bulletins }\end{array}$ \\
\hline D80 & $\begin{array}{l}\text { Dummy variable which takes the value one for the } \\
\text { years } 1981-1990 \text {, and } 0 \text { otherwise. }\end{array}$ & \\
\hline \multirow[t]{2}{*}{ D 90} & $\begin{array}{l}\text { Dummy variable which takes the value one for the } \\
\text { years 1991-2000, and } 0 \text { otherwise. }\end{array}$ & \\
\hline & Variables used in regression equation 2 & \\
\hline Grow $_{\text {it }}$ & Average growth rate of activity $\mathrm{I}$ in period $\mathrm{t}$ & $\begin{array}{l}\text { Own calculations using } \\
\text { CSO data }\end{array}$ \\
\hline Gind & Average growth rate of industrial sector in period t & $\begin{array}{l}\text { Own calculations using } \\
\text { CSO data }\end{array}$ \\
\hline Gagr & Average growth rate of agriculture in period $t$ & $\begin{array}{l}\text { Own calculations using } \\
\text { CSO data }\end{array}$ \\
\hline GTmerc & $\begin{array}{l}\text { Average growth of external trade (exports }+ \text { imports) } \\
\text { of merchandise in period } t\end{array}$ & $\begin{array}{l}\text { Own calculations using } \\
\text { data from RBI Bulletins }\end{array}$ \\
\hline GTSer & Average growth of exports of services in period t & $\begin{array}{l}\text { Own calculations using } \\
\text { data from RBI Bulletins }\end{array}$ \\
\hline Dser & $\begin{array}{l}\text { Dummy variable which takes a value one if a } \\
\text { particular services activity was liberalized } \\
\text { significantly in period t, } 0 \text { otherwise. The following } \\
\text { observations were assigned a value of } 1 \text { : hotels } 90: 1 \text {, } \\
90: 2 \text {, transport other means } 90: 2 \text {, } \\
\text { Communication } 90: 1,90: 2 \text {, banking } 80: 2,90: 1,90: 2 \text {, } \\
\text { insurance } 90: 2 \text {, business services } 90: 1,90: 2 \text {, } \\
\text { community services } 90: 2 \text {. All other observations were } \\
\text { accorded a value } 0 \text {. }\end{array}$ & $\begin{array}{l}\text { Created using } \\
\text { information from many } \\
\text { different sources }\end{array}$ \\
\hline
\end{tabular}

